\title{
Urea and sugarcane straw nitrogen balance in a soil-sugarcane crop system
}

\author{
Glauber José de Castro Gava(1), Paulo Cesar Ocheuze Trivelin(2), André Cesar Vitti(2) \\ and Mauro Wagner de Oliveira(3)
}

\begin{abstract}
(1)Agência Paulista de Tecnologia dos Agronegócios, Pólo de Desenvolvimento Regional do Centro Oeste Paulista, CEP 17201-970 Jaú, SP, Brazil. E-mail: ggava@netsite.com.br (2)Universidade de São Paulo, Centro de Energia Nuclear na Agricultura, Caixa Postal 96, CEP 13400-970 Piracicaba, SP, Brazil. E-mail: pcotrive@cena.usp.br, acvitti@cena.usp.br (3)Universidade Federal de Alagoas, Caixa Postal 24, CEP $57072-970$ Maceió, Al, Brazil. E-mail: mwagner@ceca.ufal.br
\end{abstract}

\begin{abstract}
The objectives of this study were to evaluate nitrogen utilization by sugarcane ratoon from two sources, applied urea and sugarcane straw covering soil surface (trash blanket), besides the recovery of $\mathrm{N}$ from both sources in the soil-plant system. The following treatments were established in a randomized block design with four replicates: $\mathrm{T} 1$, vinasse-urea $\left(100 \mathrm{~kg} \mathrm{ha}^{-1}\right.$ of urea-N) mixture applied on the total area of the soil covered with cane trash labeled with ${ }^{15} \mathrm{~N}$; T2, vinasse-urea mixture (urea labeled with ${ }^{15} \mathrm{~N} ; 100 \mathrm{~kg} \mathrm{ha}^{-1}$ of urea-N) applied on the total area of the soil covered with non-labeled sugarcane trash; and T3, urea- ${ }^{15} \mathrm{~N}\left(100 \mathrm{~kg} \mathrm{ha}^{-1}\right.$ of urea-N) applied in furrows at both sides of cane rows, with previous surface application of vinasse, onto soil without trash covering. The vinasse was applied at a rate of $100 \mathrm{~m}^{3} \mathrm{ha}^{-1} \mathrm{in}$ all treatments. The experiment was carried out on a Yellow Red Podzolic soil (Paleudalf), from October 1997 to August 1998, in Piracicaba, SP, Brazil. The nitrogen use efficiency of urea by the sugarcane ratoon was $21 \%$, while that of the sugarcane straw was $9 \%$. The main contributions of $\mathrm{N}$ from sugarcane trash, during one cycle, are the preservation and increase of the organic $\mathrm{N}$ in soil. The tendency for a lower accumulation of urea- $\mathrm{N}$ in the sugarcane plant, in the soil surface covered with sugarcane residue, was compensated by the assimilation of $\mathrm{N}$ from trash mineralization. Nitrogen derived from cane trash was more available to plants in the second half of the ratoon cycle.
\end{abstract}

Index terms: $\mathrm{N}$ recovery, fertilizer $-{ }^{15} \mathrm{~N}$, crop residue, mineralization, nitrogen use efficiency.

\section{Balanço do nitrogênio da uréia e da palha de cana no sistema solo-cana-de-açúcar}

Resumo - Os objetivos deste trabalho foram avaliar a utilização do nitrogênio por soqueira de cana-de-açúcar de duas fontes, uréia e palha de cana-de-açúcar, e a recuperação do N de ambas as fontes no sistema solo-planta. Os tratamentos foram estabelecidos em blocos casualizados, com quatro repetições: T1, mistura de vinhaça e uréia (100 kg ha-1 de N), aplicada em área total sobre o solo coberto com palha de cana-de-açúcar marcada com ${ }^{15} \mathrm{~N}$; T2, mistura de vinhaça e uréia (uréia marcada $\operatorname{com}^{15} \mathrm{~N}$ - uréia- ${ }^{15} \mathrm{~N} ; 100 \mathrm{~kg}$ ha ${ }^{-1}$ de $\mathrm{N}$ ) aplicada em área total sobre o solo coberto com palha de cana-de-açúcar não marcada; e T3, uréia- ${ }^{15} \mathrm{~N}$ (100 kg ha-1 de N) enterrada em sulcos laterais às linhas de cana-de-açúcar, com prévia aplicação de vinhaça sobre o solo sem palha. A vinhaça foi aplicada no volume de $100 \mathrm{~m}^{3} \mathrm{ha}^{-1}$ em todos os tratamentos. O experimento foi realizado em um Podzólico Vermelho-Amarelo (Paleudalf), entre outubro de 1997 e agosto de 1998, em Piracicaba, SP. A eficiência de uso de N da uréia pela soqueira de cana-de-açúcar foi de $21 \%$ e a de N da palha de cana-de-açúcar foi de $9 \%$. A principal contribuição do $\mathrm{N}$ da palha de cana-de-açúcar é a manutenção ou aumento do $\mathrm{N}$ orgânico do solo. A tendência de menor acumulação, pela cana-de-açúcar, do $\mathrm{N}$ da uréia no tratamento com palha, foi compensada pela acumulação de $\mathrm{N}$ proveniente da mineralização da palha. $\mathrm{O} \mathrm{N}$ da palha ficou disponível na segunda metade do ciclo da cultura.

Termos para indexação: recuperação de N, fertilizante- ${ }^{15} \mathrm{~N}$, resíduo de colheita, mineralização, eficiência de uso de nitrogênio.

\section{Introduction}

Sugarcane crop presents high efficiency of nitrogen use - taking into consideration the relationship between dry matter yield and accumulated $\mathrm{N}$ in the crop - when compared to other crops as cereals for instance (Muchow \& Robertson, 1994). However, it usually uses a low amount of $\mathrm{N}$ from the fertilizer applied to the soil, 
as well as from crop residues left on soil surface ( $\mathrm{Ng}$ Kee Kwong et al., 1987; Vallis et al., 1996a; Gava et al., 2001).

Important knowledge concerning the processes controlling $\mathrm{N}$ cycling in the sugarcane agrosystem has been obtained in studies using the stable isotope ${ }^{15} \mathrm{~N}$. These tracer experiments have indicated that the recovery of fertilizer $\mathrm{N}$ by the sugarcane crop varies from 20\% to 40\% (Sampaio et al., 1984; Yadav et al., 1990; Trivelin et al., 1995, 1996, 2002; Vallis et al., 1996a). The low recoveries of the fertilizer $\mathrm{N}$ by sugarcane might be due to: i) the microbial immobilization of $\mathrm{N}$ in the soil (Ng Kee Kwong et al., 1986; Courtaillac et al., 1998); ii) losses of $\mathrm{N}$ from the soil by denitrification or ammonia volatilization (Craswell, 1978; Freney et al., 1992); and iii) gaseous losses from the foliage of the plants (Ng Kee Kwong \& Deville, 1994; Trivelin et al., 2002). Leaching loss of fertilizer $\mathrm{N}$ might also be a cause, however previous studies have not reported high values in Brazilian sugarcane fields (Oliveira et al., 2002; Vitti, 2003).

The recovery of $\mathrm{N}$ by plants from crop residues incorporated into the soil usually varies from $5 \%$ for residues with a $\mathrm{N}$ content below $20 \mathrm{~g} \mathrm{~kg}^{-1}$ and a C:N ratio higher than 25 , up to $15 \%$ for residues with a $\mathrm{N}$ content above $20 \mathrm{~g} \mathrm{~kg}^{-1}$ and a C:N ratio lower than 25 (cereals and grasses) (Ng Kee Kwong et al., 1987; Janzen et al., 1990; Chapman et al., 1992; Myers et al., 1994). Chapman et al. (1992) found that $5 \%$ of the $\mathrm{N}$ in a crop residue labeled with ${ }^{15} \mathrm{~N}$ was assimilated by sugarcane. Ng Kee Kwong et al. (1987) also determined that the recovery by sugarcane was $11 \%$ to $14 \%$ of the $\mathrm{N}$ contained in the sugarcane straw, when this crop residue remained for eighteen months under field conditions. This amount represented less than $10 \%$ of the $\mathrm{N}$ accumulated in the whole plant.

The objectives of this study were to evaluate nitrogen utilization by sugarcane ratoon from two sources, applied urea and sugarcane straw covering soil surface (trash blanket), besides the recovery of $\mathrm{N}$ from both sources in the soil-plant system.

\section{Material and Methods}

A sugarcane crop, of the SP 80-1842 cultivar (third ratoon crop), was established on an area of Yellow Red Podzolic soil (Paleudalf), in Piracicaba, SP, Brazil. On October 10, 1997, the mechanized harvesting of the previous sugarcane crop was performed without burning the straw. The experimental design consisted of three treatments and four replicates. Each plot was constituted by 10 sugarcane rows $12 \mathrm{~m}$ long, spaced $1.4 \mathrm{~m}$, and, in the central part, there was a $2 \times 1.4 \mathrm{~m}$ subplot in which the treatments were established using either ${ }^{15} \mathrm{~N}$ labeled urea or straw. The following treatments were implemented: T1, a mixture of vinasse $\left(100 \mathrm{~m}^{3} \mathrm{ha}^{-1}\right)$ and urea (100 kg ha-1 of $\mathrm{N})$ applied evenly on the soil covered with ${ }^{15} \mathrm{~N}(1.502 \%$ atoms) labeled sugarcane straw residue; T2, a mixture of vinasse $\left(100 \mathrm{~m}^{3} \mathrm{ha}^{-1}\right)$ and labeled urea (100 kg ha-1 of N) with ${ }^{15} \mathrm{~N}$ (5.802\% atoms) applied evenly on the soil with sugarcane straw residue; and T3, labeled urea (100 kg ha ${ }^{-1}$ of N) with ${ }^{15} \mathrm{~N}(5.802 \%$ atoms) buried in $15 \mathrm{~cm}$-deep furrows, $25 \mathrm{~cm}$ away from both sides of the sugarcane rows; a previous application of vinasse $\left(100 \mathrm{~m}^{3} \mathrm{ha}^{-1}\right)$ on the soil surface, without straw covering, had been performed in this last one.

The dry matter of the sugarcane straw originally present in the field was $17 \pm 2 \mathrm{Mg} \mathrm{ha}^{-1}$ (C:N 97:1). Residues of the same sugarcane cultivar (C: $\mathrm{N}$ ratio of 125:1), labeled with ${ }^{15} \mathrm{~N}$, were used in the T1 subplots (68 $\mathrm{kg} \mathrm{ha}^{-1} \mathrm{~N}$ equivalent), replacing the original sugarcane trash. The chemical composition of the vinasse applied was $\left(\mathrm{kg} \mathrm{m}^{-3}\right)$ : N, 0.41; $\mathrm{P}_{2} \mathrm{O}_{5}, 0.07 ; \mathrm{K}_{2} \mathrm{O}, 2.72$; $\mathrm{CaO}, 0.91 ; \mathrm{MgO}, 0.38$; and $\mathrm{pH}$ (water), 4.9.

The experiment was carried out for 315 days, from October 1997 to August 1998. The averages of the maximum and minimum air temperatures were $30.0^{\circ} \mathrm{C}$ and $15.8^{\circ} \mathrm{C}$, respectively, and the total rainfall over the period reached $1,335 \mathrm{~mm}$.

The harvest of the subplot plants of the treatments with urea- ${ }^{15} \mathrm{~N}$ and straw- ${ }^{15} \mathrm{~N}$ was accomplished from August 16 to 24, 1998, according to the procedure defined by Trivelin et al. (1994, 1995, 1996). Harvested plants of sugarcane in the subplots were divided into tops (green leaves and stalk top), dry leaves and stalks. The sampling of the residual trash was performed on subplots of treatments T1 and T2. The soil of the central part of subplots was excavated to make $30 \mathrm{~cm}$ deep trenches of 50x50 cm to sample rhizomes, roots, and soil. Nitrogen content $\left(\mathrm{g} \mathrm{kg}^{-1}\right.$ ) and abundance of ${ }^{15} \mathrm{~N}$ (\% atoms) were determined for all samples by mass spectrometry: 20-20 model spectrometer coupled to an ANCASL analyzer from Europe Scientific, UK.

Using data of dry matter, $\mathrm{N}$ content and abundance of ${ }^{15} \mathrm{~N}$ of sugarcane, residual trash and soil samples, it was possible to calculate the $\mathrm{N}$ in plant, residual trash and soil, which is derived from the source- ${ }^{15} \mathrm{~N}$ (Ndfs), 
as well as the recovery (R) of the $\mathrm{N}$ from the sources present in each compartment (Trivelin et al., 1994, 1995, 1996):

$\mathrm{TN}=(\mathrm{DM})(\mathrm{NC})$

Ndfs $=[(a-0.367) /(b-0.367)] N C$

$\mathrm{R}=[(\mathrm{Ndfs}) /(\mathrm{NR})] 100$

in which $\mathrm{TN}$ is the total $\mathrm{N}\left(\mathrm{kg} \mathrm{ha}^{-1}\right)$ in a considered compartment (parts of plant, residual trash or soil); DM and $\mathrm{NC}$ are, respectively, the dry matter $\left(\mathrm{Mg} \mathrm{ha}^{-1}\right)$ and the $\mathrm{N}$ content $\left(\mathrm{kg} \mathrm{Mg}^{-1}\right)$ in a compartment; Ndfs is the $\mathrm{N}$ in plant, residual trash or soil derived from the source- ${ }^{15} \mathrm{~N}$ (urea or sugarcane straw); $\mathrm{a}$ and $\mathrm{b}$ are the abundances of ${ }^{15} \mathrm{~N}$, respectively, in the samples (plant, residual trash and soil) at the harvest and in the source- $-15 \mathrm{~N}$ at the beginning and 0.367 is the ${ }^{15} \mathrm{~N}$ natural abundance; $\mathrm{R}$ is the percentage of $\mathrm{N}$ recovery of a source- $\mathrm{N}$ in each compartment or in the soil-plant system. NR is the $\mathrm{N}$ rate of applied urea or in the sugarcane straw.

The results were submitted to variance analysis ( $F$ test, at $95 \%$ ) and treatments compared by the Duncan test at $5 \%$ probability.

\section{Results and Discussion}

\section{Recovery by the sugarcane ratoon of $\mathrm{N}$ applied either as urea or as straw}

The results of treatments with urea- ${ }^{15} \mathrm{~N}$ (T2 and T3) presented no differences. However, averages indicated a tendency for a lower urea- $\mathrm{N}$ recovery when the fertilizer was applied on the soil covered with straw (Table 1). Ng Kee Kwong et al. (1987) studied the effect of the contribution of $10 \mathrm{Mg} \mathrm{ha}^{-1}$ sugarcane straw to the soil, and found that the fertilizer $\mathrm{N}$ recovery by sugarcane was reduced to $9 \%$ in relation to the treatment that did not receive any straw. Possible explanations for this lower recovery of the fertilizer $\mathrm{N}$ are the increased immobilization of the $\mathrm{N}$ by the soil microbial biomass and the increased fertilizer $\mathrm{N}$ losses, mainly, gaseous (Craswell, 1978; Freney et al., 1992).

The urea- $\mathrm{N}$ accumulated by sugarcane in treatments T2 and T3 represented, on the average, 16 and $26 \mathrm{~kg} \mathrm{ha}^{-1}$ and there was a recovery of $16 \%$ and $26 \%$ of the applied fertilizer $\mathrm{N}$, respectively (Table 1 ). These results are similar to those obtained by Vallis et al. (1996a), Courtaillac et al. (1998) and Trivelin et al. (2002), when working under different climatic conditions and soil management as well.

Courtaillac et al. (1998) evaluated the recovery of urea- ${ }^{15} \mathrm{~N}$ in sugarcane ratoon and obtained values varying from $12 \%$ to $18 \%$ of fertilizer $\mathrm{N}$. These values might be considered low when compared to $33 \%$ obtained by Vallis et al. (1996a) for two soil types, with and without straw covering.

Trivelin et al. (2002) found that the recovery of urea$\mathrm{N}$ in the whole sugarcane plant is affected not only by soil cover, but also by the place in which the fertilizer was applied. Surface applications of urea without or with straw cover allowed recoveries of $25 \%$ and $9 \%$, respectively, and, when urea was buried into the soil, recoveries of $43 \%$ and $36 \%$, respectively, were observed.

The $\mathrm{N}$ in the parts of sugarcane derived from the straw- ${ }^{15} \mathrm{~N}$ in $\mathrm{T} 1$ was different from that of the other treatments (Table 1). Out of the $68 \mathrm{~kg} \mathrm{ha}^{-1} \mathrm{~N}$ of straw, only $6 \mathrm{~kg} \mathrm{ha}^{-1}$ were accumulated in the sugarcane, corresponding to a recovery of 9\%. Ng Kee Kwong et al. (1987) and Chapman et al. (1992), using sugarcane straw${ }^{15} \mathrm{~N}$ obtained similar results. On the average, $5 \%$ to $10 \%$ of the total $\mathrm{N}$ contained in trash were recovered by

Table 1. Dry matter yield (DM), total nitrogen (TN), nitrogen in the plant derived from the source- ${ }^{15} \mathrm{~N}$ (Ndfs) and recovery (R) of nitrogen from straw or urea by sugarcane ratoon ${ }^{(1)}$.

\begin{tabular}{|c|c|c|c|c|}
\hline Plant part & $\begin{array}{c}\mathrm{DM} \\
\left(\mathrm{Mg} \mathrm{ha}^{-1}\right)\end{array}$ & TN & $\begin{array}{c}\text { Ndfs } \\
\left.a^{-1}\right) \text {--- }\end{array}$ & $\begin{array}{c}\mathrm{R} \\
(\%) \\
\end{array}$ \\
\hline & \multicolumn{4}{|c|}{$\mathrm{T} 1^{(2)}$} \\
\hline Top & $4 \pm 1$ & $40 \pm 8$ & $1.7 \pm 0.4 \mathrm{a}$ & 2 \\
\hline Dry leaf & $9 \pm 2$ & $35 \pm 10$ & $0.4 \pm 0.1 \mathrm{a}$ & 1 \\
\hline Stalk & $21 \pm 5$ & $61 \pm 14$ & $3.1 \pm 0.8 \mathrm{a}$ & 5 \\
\hline Root & $5 \pm 1$ & $42 \pm 6$ & $0.7 \pm 0.2 \mathrm{a}$ & 1 \\
\hline \multirow[t]{2}{*}{ Whole plant } & $39 \pm 5$ & $178 \pm 18$ & $5.9 \pm 0.4 \mathrm{a}$ & 9 \\
\hline & \multicolumn{4}{|c|}{$\mathrm{T} 2^{(3)}$} \\
\hline Top & $4 \pm 1$ & $43 \pm 10$ & $4.1 \pm 1.7 b$ & 4 \\
\hline Dry leaf & $8 \pm 1$ & $30 \pm 5$ & $3.4 \pm 0.9 b$ & 3 \\
\hline Stalk & $20 \pm 3$ & $59 \pm 16$ & $5.9 \pm 2.4 \mathrm{~b}$ & 6 \\
\hline Root & $5 \pm 1$ & $36 \pm 8$ & $2.8 \pm 0.4 b$ & 3 \\
\hline \multirow[t]{2}{*}{ Whole plant } & $37 \pm 4$ & $168 \pm 22$ & $16.2 \pm 3.0 \mathrm{~b}$ & 16 \\
\hline & \multicolumn{4}{|c|}{$\mathrm{T} 3^{(4)}$} \\
\hline Top & $4 \pm 1$ & $42 \pm 11$ & $6.6 \pm 2.7 b$ & 7 \\
\hline Dry leaf & $8 \pm 1$ & $27 \pm 2$ & $4.8 \pm 1.3 b$ & 5 \\
\hline Stalk & $22 \pm 2$ & $67 \pm 12$ & $10.3 \pm 2.8 \mathrm{~b}$ & 10 \\
\hline Root & $5 \pm 1$ & $38 \pm 7$ & $4.3 \pm 2.3 b$ & 4 \\
\hline Whole plant & $39 \pm 2$ & $174 \pm 19$ & $26.0 \pm 6.0 \mathrm{~b}$ & 26 \\
\hline
\end{tabular}

(1)Averages and standard deviations of mean ( $\mathrm{a} \pm \mathrm{se}$ ) of four replicates; the averages for the same plant part, among the treatments, followed by different letters differ by Duncan test at $5 \%$ of probability. ${ }^{(2)} \mathrm{T} 1$ : a mixture of vinasse and urea applied evenly on the soil covered with ${ }^{15} \mathrm{~N}$ (1.502\% atoms) labeled sugarcane straw residue. ${ }^{(3)} \mathrm{T} 2$ : a mixture of vinasse and labeled urea with ${ }^{15} \mathrm{~N}$ (5.802\% atoms) applied evenly on the soil with sugarcane straw residue. ${ }^{(4)} \mathrm{T} 3$ : labeled urea with ${ }^{15} \mathrm{~N}$ (5.802\% atoms) buried in $15 \mathrm{~cm}$-deep furrows, $25 \mathrm{~cm}$ away from both sides of the sugarcane rows; a previous application of vinasse on the soil surface, without straw covering, was performed in the last one. 
sugarcane. Possibly, $\mathrm{N}$ was mineralized from the easily decomposable sugarcane residue (free aminoacids, nucleic acids and nucleotides) and immediately immobilized in the microbial biomass or complexed by phenolic components derived from the degradation of the lignin of the straw, thus becoming unavailable to the plant (Martin \& Haider, 1980).

For the straw- ${ }^{15} \mathrm{~N}$ treatment, $7 \%$ of the total $\mathrm{N}$ in the plant, derived from the source (Ndfs), were present in dry leaves, $29 \%$ in tops, $52 \%$ in stalks, and $12 \%$ in the underground part (Table 1). In T2, 21\% of the total Ndfs were allocated to dry leaves, $26 \%$ to tops, $36 \%$ to stalks, and $17 \%$ to underground parts; in T3, $19 \%$ were allocated to dry leaves, 25\% to tops, 39\% to stalks, and $17 \%$ to underground parts. These results indicate that the mineralized $\mathrm{N}$ from the straw was available to the sugarcane ratoon only at the second half of the cropping period. In the straw $-{ }^{15} \mathrm{~N}$ treatment, only $7 \%$ of the total Ndfs were accumulated in dry leaves, thus differing from the other treatments in which Ndfs in dry leaves averaged $20 \%$. At the beginning of the cycle, when the earlier leaves were metabolically active, mineralized $\mathrm{N}$ from the straw- ${ }^{15} \mathrm{~N}$ source in $\mathrm{T} 1$ was relatively unavailable, due to the high C:N ratio of the trash material. An important contribution of the straw in sugarcane fields is the maintenance of organic $\mathrm{N}$ in the soil ( $\mathrm{Ng}$ Kee Kwong et al., 1987; Wood, 1991; Vallis et al., 1996b).

It may be emphasized that Ndfs (fertilizer $\mathrm{N}$ and straw-N) represented a small fraction of total $\mathrm{N}$ in the sugarcane ratoon. This fact indicates other $\mathrm{N}$ sources, like mineralization of native soil organic matter (Stanford et al., 1965; Ng Kee Kwong et al., 1987), biological N fixation (Urquiaga et al., 1992), and absorption by foliage of ammonia from the air (Farquhar et al., 1980; Holtan-Hartwing \& Bockman, 1994) also contribute in supplying $\mathrm{N}$ to sugarcane. It is important to mention the effects in the soil when fertilizer $\mathrm{N}$ is applied on the presence of fresh organic matter, such as "pool substitution" and a "priming effect”, that led Jenkinson et al. (1985) to propose the ANI concept (Added Nitrogen Interaction). In experiments using ${ }^{15} \mathrm{~N}$-labeled fertilizer, according to Polwson \& Barraclough (1993), it is often observed that uptake of unlabeled $\mathrm{N}$ is greater in plants receiving labeled fertilizer than in the unfertilized control. Thus, as a result of "pool substitution", labeled inorganic $\mathrm{N}$ from added fertilizer substitutes unlabeled inorganic $\mathrm{N}$ that would otherwise have been immobilized. Under these conditions, as those found in this experiment, underestimation probably occurred in recovering fertilizer
$\mathrm{N}$ by the ${ }^{15} \mathrm{~N}$ technique, therefore the use of $\mathrm{N}$ from other sources could have been overestimated.

\section{Recovery of $\mathbf{N}$ from either applied urea or sugarcane straw in the soil}

For treatments with urea- ${ }^{15} \mathrm{~N}$, the Ndfs in the soil compartment were the same; however, when summing the Ndfs values found in the residual straw $\left(8.3 \mathrm{~kg} \mathrm{ha}^{-1}\right)$, it is verified that the value of the total recovery in T2 (44\%) was superior to that in T3 (37\%) (Table 2). These results are similar to those found by Ng Kee Kwong et al. (1987), who observed average values of $27 \%$ and $18 \%$ in soils with and without straw, respectively. Trivelin et al. (2002) also found similar results, since $\mathrm{N}$ recoveries from urea in the soil were $43 \%$ and $31 \%$ for soils with and without trash, respectively. The straw, probably, caused the immobilization of fertilizer N. In the present work, on the average, $36 \%$ of urea- $\mathrm{N}$ remained in the soil.

Ng Kee Kwong et al. (1986), Vallis et al. (1996a) and Courtaillac et al. (1998) also obtained similar results. This amount of fertilizer $\mathrm{N}$ recovered in the soil has been attributed to microbial immobilization (Ng Kee Kwong et al., 1986), as well as to $\mathrm{NH}_{4}^{+}$fixation by the claymineral complex. Nine percent of $\mathrm{N}$ from the sugarcane straw were in the $0-30 \mathrm{~cm}$ soil layer, and, on average, $81 \%$ of the straw-N were on soil surface after almost one year in T1, which indicates that the decomposition of the sugarcane straw was rather slow (Table 2). Eight percent of the urea- $\mathrm{N}$ were present in the residual straw

Table 2. Nitrogen in the soil or in the residual straw derived from the source labeled with ${ }^{15} \mathrm{~N}$ (Ndfs) and recovery (R) of $\mathrm{N}$ from either straw or urea in both the soil and residual straw ${ }^{(1)}$.

\begin{tabular}{|c|c|c|c|c|}
\hline \multicolumn{2}{|c|}{ Soil } & \multicolumn{2}{|c|}{ Residual straw } & Total \\
\hline $\begin{array}{c}\text { Ndfs } \\
\left(\mathrm{kg} \mathrm{ha}^{-1}\right)\end{array}$ & $\begin{array}{l}\mathrm{R}_{1} \\
(\%)\end{array}$ & $\begin{array}{c}\text { Ndfs } \\
\left(\mathrm{kg} \mathrm{ha}^{-1}\right)\end{array}$ & $\begin{array}{l}\mathrm{R}_{2} \\
(\%)\end{array}$ & $\begin{array}{c}\mathrm{R}_{1}+\mathrm{R}_{2} \\
(\%)\end{array}$ \\
\hline $6.4 \pm 5 \mathrm{a}$ & 9 & $\begin{array}{c}\mathrm{T} 1^{(2)} \\
55.2 \pm 25 \mathrm{a}\end{array}$ & 81 & 90 \\
\hline $35.6 \pm 7 b$ & 36 & $\begin{array}{c}\mathrm{T} 2^{(3)} \\
8.3 \pm 2 \mathrm{~b}\end{array}$ & 8 & 44 \\
\hline $37.3 \pm 11 \mathrm{~b}$ & 37 & $\begin{array}{r}\mathrm{T}^{(4)} \\
-^{(5)} \\
\end{array}$ & - & 37 \\
\hline
\end{tabular}

(1)Averages and standard deviations of mean ( $a \pm s e)$ of four replicates; the averages for the same plant part, among the treatments, followed by different letters differ by Duncan test at $5 \%$ of probability. ${ }^{(2)} \mathrm{T} 1$ : a mixture of vinasse and urea applied evenly on the soil covered with ${ }^{15} \mathrm{~N}$ (1.502\% atoms) labeled sugarcane straw residue. ${ }^{(3)} \mathrm{T} 2$ : a mixture of vinasse and labeled urea with ${ }^{15} \mathrm{~N}$ (5.802\% atoms) applied evenly on the soil with sugarcane straw residue. ${ }^{(4)} \mathrm{T} 3$ : labeled urea with ${ }^{15} \mathrm{~N}$ (5.802\% atoms) buried in $15 \mathrm{~cm}$-deep furrows, $25 \mathrm{~cm}$ away from both sides of the sugarcane rows; a previous application of vinasse on the soil surface, without straw covering, was performed in the last one. (5)Without residual straw. 
in T2. The slow movement of the straw-N into the soil reinforces the idea of the slow mineralization of this residue- $\mathrm{N}$, which remains unavailable to the plants. The result obtained for $\mathrm{T} 1$ was close to those found by $\mathrm{Ng}$ Kee Kwong et al. (1987), in which 73\% to 83\% N from sugarcane straw remained in the organic matter of the soil. According to these results, it is possible to infer that the straw $\mathrm{N}$ has a greater importance as a reserve pool of organic $\mathrm{N}$ in the soil, compared to the urea source. Probably, the contribution of this source will be relevant either for the maintenance or the increase of soil fertility in the long term, as emphasized by $\mathrm{Ng}$ Kee Kwong et al. (1987) and Janzen et al. (1990).

Total recovery of $\mathbf{N}$ from urea or straw in the soilplant system

One forty and $37 \%$ of the $\mathrm{N}$ added in straw or urea form was not recovered in the sugarcane, soil or residual straw in treatments $\mathrm{T} 1, \mathrm{~T} 2$ and $\mathrm{T} 3$, respectively (Figure 1). Approximately 9\% of the straw- $\mathrm{N}$ were not recovered in an experiment carried out by $\mathrm{Ng}$ Kee Kwong et al. (1987). The unrecovered $\mathrm{N}$ from the straw is low when compared to unrecovered urea- $\mathrm{N}$ that averaged 39\%. The result of unrecovered urea- $\mathrm{N}$ presents the same magnitude of that obtained by Courtaillac et al. (1998) or by Chapman et al. (1994), which varied from $36 \%$ to $64 \%$, but was greater than $20 \%$, found by Ng Kee Kwong et al. (1987). Since the experiment was carried out under field conditions, in addition to the possible experimental uncontrolled errors, unrecovered $\mathrm{N}$ from the ${ }^{15} \mathrm{~N}$ sources also includes not determined $\mathrm{N}$ in the soil profile, losses of the soil $\mathrm{N}$ by

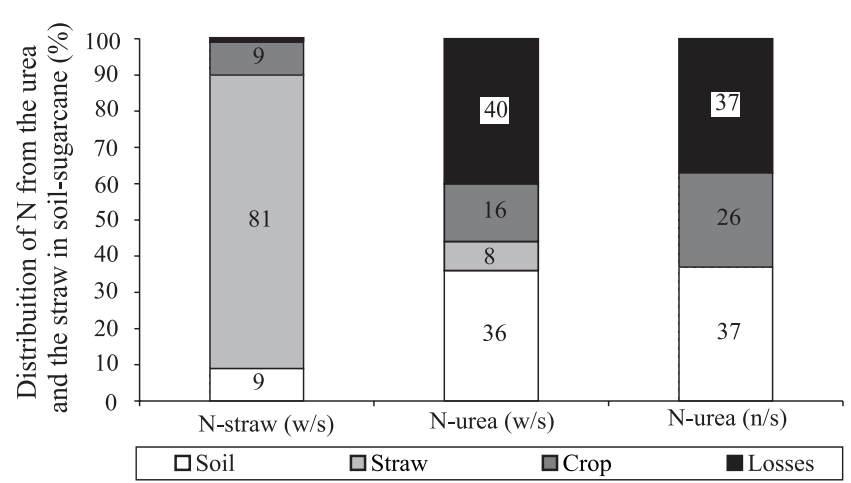

Figure 1. Total recovery of $\mathrm{N}$ from either urea or straw in the soil-plant system in a sugarcane field with straw (w/s) or without straw (n/s) covering. leaching, ammonia volatilization, and denitrification, as well as ammonia volatilization by the aerial part added to the transpiration flow at the leaf senescence stage.

The recovery of $\mathrm{N}$ from either straw or fertilizer by sugarcane was $9 \%, 16 \%$ and $26 \%$ for $\mathrm{T} 1$, $\mathrm{T} 2$, and $\mathrm{T} 3$, respectively (Table 1 and Figure 1). The sum of recovered $\mathrm{N}$ from urea and straw for T1 and T2 (25\%) is practically the same as the recovery of the urea- $\mathrm{N}$ in T3 (26\%). The tendency to a lower recovery by the plant of urea- $\mathrm{N}$ for the treatment with straw covering soil surface (T2) was compensated by $\mathrm{N}$ uptake from the straw (T1). According to these results one may infer that the immobilization of fertilizer $\mathrm{N}$ may be facilitating the mineralization of the straw- $\mathrm{N}$.

In the long term, sugarcane harvests without burning the straw contributes to the maintenance and increase of soil organic matter (SOM), according to Wood (1991) and Graham et al. (2002). The results of this work agree with this statement, since $91 \% \mathrm{~N}$ from plant residues remained in the soil after almost a year.

Although sugarcane residues present a low content of $\mathrm{N}$ compared to the reserve in the soil, the straw deposited on the soil on successive harvestings will contribute not only to the increase of SOM, but also to the readily mineralizable nitrogen and mineral $\mathrm{N}$ :total $\mathrm{N}$ ratio on soil surface (Graham et al., 2002).

\section{Conclusions}

1. The $\mathrm{N}$ from the cane straw left on the sugarcane field maintains and increases the organic-N pool in the soil.

2. The tendency to a lower utilization of urea- $\mathrm{N}$ by sugarcane with trash on the soil surface is compensated by the assimilation of $\mathrm{N}$ from crop residues.

3. Straw-N availability to the plant occurs more in the second half of the cropping cycle.

\section{Acknowledgements}

To CNPq, for the scholarship to the authors; to Fapesp, for financial support; to Usina Iracema S/A, for logistic support; to Claudimir P. Penatti and José A. Forti from Copersucar, for their collaboration.

\section{References}

CHAPMAN, L.S.; HAYSOM, M.B.C.; SAFFIGNA, P.G. N cycling in cane fields from ${ }^{15} \mathrm{~N}$ labeled trash and residual fertilizer. In: AUSTRALIAN SOCIETY OF SUGAR CANE TECHNOLOGISTS, 
14., Brisbane, 1992. Proceedings. Brisbane: Watson Ferguson, 1992. p.84-89.

CHAPMAN, L.S.; HAYSOM, M.B.C.; SAFFIGNA, P.G. The recovery of ${ }^{15} \mathrm{~N}$ from labeled urea fertilizer in crop components of sugarcane and in soil profiles. Australian Journal of Agricultural Research, v.45, p.1577-1585, 1994.

COURTAILLAC, N.; BARAN, R.; OLIVER, R.; CASABIANCA, H.; GANRY, F. Efficiency of nitrogen fertilizer in sugarcane-vertical system in Guadeloupe according to growth and ratoon age of the cane. Nutrient Cycling in Agroecosystems, v.52, p.9-17, 1998.

CRASWELL, E.T. Some factors influencing denitrification and nitrogen immobilization in a clay soil. Soil Biology \& Biochemistry, v.10, p.241-245, 1978.

FARQUHAR, G.D.; FIRTH, P.M.; WETSELAAR, R.; WEIR, B. On the gaseous exchange of ammonia between leaves and the environment: determination of the ammonia compensation point. Plant Physiology, v.66, p.710-714, 1980.

FRENEY, J.R.; DENMEAD, O.T.; WOOD, A.W.; SAFFIGNA, P.G.; CHAPMAN, L.S.; HAM, G.J.; HURNEY, A.P.; STEWART, R.L. Factors controlling ammonia loss from trash covered sugarcane fields fertilized with urea. Fertilizer Research, v.31, p.341-349, 1992.

GAVA, G.J.C.; TRIVELIN, P.C.O.; OLIVEIRA, M.W.; PENATTI, C.P. Crescimento e acúmulo de nitrogênio em cana-de-açúcar cultivada em solo coberto com palhada. Pesquisa Agropecuária Brasileira, v.36, p.1347-1354, 2001.

GRAHAM, M.H.; HAYNES, R.J.; MEYER, J.H. Soil organic matter content and quality: effects of fertilizer applications, burning and trash retention on a long-term sugarcane experiment in South Africa. Soil Biology \& Biochemistry, v.34, p.93-102, 2002.

HOLTAN-HARTWIG, L.; BOCKMAN, O.C. Ammonia exchange between crops and air. Norwegian Journal of Agricultural Sciences, v.14, 1994. 41p. supplement.

JANZEN, H.H.; BOLE, J.B.; BIEDERBECK, V.O.; SLINKARD, A.E. Fate of $\mathrm{N}$ applied as green manure or ammonium fertilizer to soil subsequently cropped with spring wheat at three sites in western Canada. Canadian Journal of Soil Science, v.70, p.313-323, 1990.

JENKINSON, D.S.; FOX, R.A.; RAYNER, J.H. Interactions between fertilizer nitrogen and soil nitrogen: the so called "priming effect”. Journal of Soil Science, v.36, p.425-444, 1985.

MARTIN, J.P.; HAIDER, K. Microbial degradation and stabilization of ${ }^{14} \mathrm{C}$-labeled lignins, phenols, and phenolic polymers in relation to soil humus formation. In: KIRK, T.K.; HIGUCHI, T.; CHANG, H.M. (Ed.). Lignin biodegradation: microbiology, chemistry and potential applications. Boca Raton: CRC Press, 1980. v.1. p.77100.

MUCHOW, R.C.; ROBERTSON, M.J. Relating crop nitrogen uptake to sugarcane yield. In: AUSTRALIAN SOCIETY OF SUGAR CANE TECHNOLOGISTS, Townsville, 1992. Proceedings. Queensland: Watson Ferguson, 1994. p.122-129.

MYERS, R.J.K.; PALM, C.A.; CUEVAS, E.; GUNATILLEKE, I.U.N.; BROSSARD, M. The synchronization of nutrient mineralization and plant nutrient demand. In: WOOMER, P.L.; SWIFT, M.J. (Ed.). The biological management of tropical soil fertility. New York: Wiley-Sayce Publications, 1994. p.81-112.

NG KEE KWONG, K.F.; DEVILLE, J. The course of fertilizer nitrogen uptake by rainfed sugarcane in Mauritius. Journal of Agricultural Science, v.122, p.385-391, 1994.

NG KEE KWONG, K.F.; DEVILLE, J.; CAVALOT, P.C.; RIVIERE, $\mathrm{V}$. Biological immobilization of fertilizer nitrogen in humid tropical soils of Mauritius. Soil Science, v.141, p.195-199, 1986.

NG KEE KWONG, K.F.; DEVILLE, J.; CAVALOT, P.C.; RIVIERE, $\mathrm{V}$. Value of cane trash in nitrogen nutrition of sugarcane. Plant and Soil, v.102, p.79-83, 1987.

OLIVEIRA, M.W.; TRIVELIN, P.C.O.; BOARETTO, A.E.; MURAOKA, T.; MORTATTI, J. Leaching of nitrogen, potassium, calcium and magnesium in a sandy soil cultivated with sugarcane. Pesquisa Agropecuária Brasileira, v.37, p.861-868, 2002.

POWLSON, D.S.; BARRACLOUGH, D. Mineralization and assimilation in soil-plant systems. In: KNOWLES, R.; BLACKBURN, T.H. (Ed.). Nitrogen isotope techniques. San Diego: Academic Press, 1993. p.209-242.

SAMPAIO, E.V.S.B.; SALCEDO, I.H.; BETTAMY, J. Dinâmica de nutrientes em cana-de-açúcar: I - Eficiência de utilização de uréia${ }^{15} \mathrm{~N}$ em aplicação única ou parcelada. Pesquisa Agropecuária Brasileira, v.19, p.943-949, 1984.

STANFORD, G.; AYRES, A.S.; DOI, M. Mineralizable soil nitrogen in relation to fertilizer needs of sugarcane in Hawaii. Soil Science, v.99, p.132-137, 1965.

TRIVELIN, P.C.O.; LARACABEZAS, W.A.R.; VICTORIA, R.L.; REICHARDT, K. Evaluation of a ${ }^{15} \mathrm{~N}$ plot design for estimating plant recovery of fertilizer nitrogen applied to sugar cane. Scientia Agricola, v.51, p.226-234, 1994.

TRIVELIN, P.C.O.; OLIVEIRA, M.W.; VITTI, A.C.; GAVA, G.J.C.; BENDASSOLLI, J.A. Perdas do nitrogênio da uréia no sistema soloplanta em dois ciclos de cana-de-açúcar. Pesquisa Agropecuária Brasileira, v.37, p.193-201, 2002.

TRIVELIN, P.C.O.; RODRIGUES, J.C.S.; VICTORIA, R.L. Utilização por soqueira de cana-de-açúcar de início de safra do nitrogênio da aquamônia- ${ }^{15} \mathrm{~N}$ e uréia- ${ }^{15} \mathrm{~N}$ aplicado ao solo em complemento à vinhaça. Pesquisa Agropecuária Brasileira, v.31, p.89-99, 1996.

TRIVELIN, P.C.O.; VICTORIA, R.L.; RODRIGUES, J.C.S. Aproveitamento por soqueira de cana-de-açúcar de final de safra do nitrogênio da aquamônia- ${ }^{15} \mathrm{~N}$ e uréia- ${ }^{15} \mathrm{~N}$ aplicado ao solo em complemento à vinhaça. Pesquisa Agropecuária Brasileira, v.30, p.1375-1385, 1995.

URQUIAGA, S.; CRUZ, K.H.S.; BODDEY, R.M. Contribution of nitrogen fixation to sugar cane: Nitrogen-15 and nitrogen balance estimates. Soil Science Society of America Journal, v.56, p.105114, 1992.

VALLIS, I.; CATCHPOOLE, V.R.; HUGHES, R.M.; MYERS, R.J.K.; RIDGE, D.R.; WEIER, K.L. Recovery in plants and soils of 
${ }^{15} \mathrm{~N}$ applied as subsurface bands of urea to sugarcane. Australian Journal of Agricultural Research, v.47, p.355-370, 1996a.

VALLIS, I.; PARTON, W.J.; KEATING, B.A.; WOOD, A.W. Simulation of the effects of trash and $\mathrm{N}$ fertilizer management on soil organic matter levels and yields of sugarcane. Soil Tillage Research, v.38, p.115-132, 1996b.

VITTI, A.C. Adubação nitrogenada da cana-de-açúcar (soqueira) colhida mecanicamente sem a queima prévia: manejo e efeito na produtividade. 2003. 114p. Tese (Doutorado) - Centro de Energia Nuclear na Agricultura, Piracicaba.

WOOD, A.W. Management of crop residues following green harvesting of sugarcane in north Queensland. Soil \& Tillage Research, v.20, p.69-85, 1991.

YADAV, R.L.; KUMAR, R.; VERMA, R.S. Effects of nitrogen applied through different carriers on yield and quality of sugarcane. Journal of Agricultural Science, v.114, p.225-230, 1990.

$\overline{\text { Received on August 18, } 2004 \text { and accepted on February 10, } 2005}$ 